\title{
Pengaruh Pemberian Probiotik Lactobacillus acidophilus dan Bifidobacterium terhadap Produksi Ayam Petelur yang Diinfeksi Escherichia coli
}

\author{
The Effect of Probiotic Lactobacillus acidophilus and Bifidobacterium on Production Laying \\ of Infected Escherichia coli
}

\section{K. Huda, W. P. Lokapirnasari, Soeharsono, S. Hidanah, N. Harijani, dan R. Kurnijasanti}

\author{
Pasca Sarjana Progam Studi Agribisnis Veteriner, Fakultas Kedokteran Hewan, \\ Universitas Airlangga Surabaya, Kampus C, Mulyorejo, Surabaya \\ Corresponding e-mail: khoirulh779@gmail.com
}

\begin{abstract}
The purpose of this study was to determine the use of probiotics Lactobacillus acidophilus and Bifidobacterium sp on feed consumption and Hen Day Production (HDP), layer was infected with Escherichia coli. About 120 layers at 25 weeks of age were randomized into six treatments. The treatment consisted of factors a (infection and non-infection Escherichia coli) and factor b (basal feed, AGP and probiotics). The results of the study gave probiotics an effect $(\mathrm{p}<0.05)$ on feed consumption, HDP and egg weight. Infection factors have an effect ( $p$ $<0.05$ ) on HDP but have no effect ( $p>0.05$ ) on feed consumption and egg weight. There was interactions between probiotic and infection factors $(p<0.05)$ on HDP and egg weight but there was no interaction $(p>0.05)$ between probiotic and infection factors on feed consumption. The highest feed consumption was found in the treatment of infectious probiotics is $114.7 \mathrm{~g}$, the highest HDP was treated with non-infectious probiotics is $98.6 \%$, the highest egg weight was treated with non-infectious probiotics is $60.5 \mathrm{~g}$. It could be concluded that the administration of probiotics can produce good production performance and high profits.
\end{abstract}

Key words: Production, infection, probiotic, interactions

\begin{abstract}
ABSTRAK
Penelitian ini bertujuan untuk mengetahui penggunaan probiotik Lactobacillus acidophilus dan Bifidobacterium sp terhadap konsumsi pakan dan Hen Day Production (HDP) ayam petelur yang diinfeksi Escherichia coli. Sebanyak 120 ekor ayam petelur umur 25 minggu diacak menjadi 6 perlakuan, masing-masing perlakuan terdiri dari 4 ulangan dan setiap ulangan terdiri dari 5 ekor ayam petelur. perlakuan terdiri dari faktor a (infeksi dan non infeksi Escherichia coli) dan faktor b (pakan basal, AGP dan probiotik). Hasil penelitian Pemberian probiotik berpengaruh $(\mathrm{p}<0,05)$ terhadap konsumsi pakan, HDP dan berat telur. Faktor infeksi berpengaruh $(p<0,05)$ terhadap HDP tetapi tidak berpengaruh $(p>0,05)$ terhadap konsumsi pakan dan berat telur. Terdapat interaksi antara faktor probiotik dan infeksi $(\mathrm{p}<0,05)$ terhadap HDP dan berat telur tetapi tidak terdapat interaksi $(\mathrm{p}>0,05)$ antara faktor probiotik dan infeksi terhadap konsumsi pakan. Konsumsi pakan tertinggi terdapat pada perlakuan pemberian probiotik diinfeksi yaitu 114,7 g, HDP tertinggi perlakuan pemberian probiotik noninfeksi yaitu 98,6\% dan berat telur tertinggi terdapat pada perlakuan probiotik noninfeksi yaitu 60,5 g. Dapat disimpulkan bahwa pemberian probiotik Lactobacillus acidophilus dan Bifidobacterium sp dapat menghasilkan performa produksi yang baik dan keuntungan yang tinggi.
\end{abstract}

Kata kunci: Produksi, infeksi, probiotik, interaksi

\section{PENDAHULUAN}

Penggunaan antibiotik atau antimikroorganisme sebagai bahan aditif dalam pakan ternak telah berlangsung lebih dari 40 tahun. Meningkatnya permintaan pasar terhadap telur dan daging ayam tidak seimbang dengan hasil produksi oleh peternak unggas di Indonesia. Hal ini mendorong peternak untuk meningkatkan produksi ternak unggas. Salah satu upaya peternak yaitu dengan penggunaan Antibiotic Growth-promotor (AGP) untuk meningkatkan produksi (Ratclif, 2001).

Biaya pakan mencapai $60-70 \%$ dari total biaya usaha peternakan ayam petelur, 
oleh karena itu perlu dilakukan upaya untuk meningkatkan efisiensi pakan agar ternak dapat optimal penyerapan nutrisinya. Feed additive seperti Antibiotic Growth-promotor (AGP) yang banyak digunakan untuk memacu produksi tersebut, diindikasikan memiliki efek negatif antara lain dapat menimbulkan residu dalam daging dan produk hewani lainnya yang dapat berpengaruh terhadap kesehatan konsumen, resistensi bakteri terhadap antibiotik serta terjadinya resistensi silang antara antibiotika dalam satu golongan. Menurut Haryati (2011) bahwa pengganti antibiotik antara lain probiotik, prebiotik, asam organik (acidifier), enzim dan mineral organik.

Penambahan probiotik dapat mengurangi kemampuan mikroorganisme patogen dalam memproduksi toksin, mengurangi efek negatif yang diakibatkan adanya hambatan pakan (berupa anti nutrisi) karena probiotik mampu menstimulasi peningkatan ketersediaan zat makanan, merangsang produksi enzim pencernaan serta dihasilkannya vitamin dan substansi antimikrobial sehingga meningkatkan status kesehatan saluran pencernaan (Sumarsih et al., 2012)

Lactobacillus acidophilus dan

Bifidobacterium $s p$ merupakan bakteri yang mempunyai karakteristik dan jalur pembentukan asam laktat yang berbeda. Lactobacillus acidophilus merupakan golongan bakteri asam laktat dalam pembentukan asam laktat melalui jalur hormofermentatif (Umam et al., 2012). Keuntungan yang diberikan oleh Bifidobacterium $s p$ terhadap kesehatan antara lain dapat memiliki aktifitas antikarsinogenik dan mengurangi kadar kolesterol dalam serum, selain itu juga memberikan efek menguntungkan bagi kesehatan karena bakteri tersebut dapat mengurangi laktosa, meningkatkan respon kekebalan terhadap tubuh dan menghambat enzim yang berbahaya (Mulyani et al., 2008)

Penyakit yang disebabkan Escherichia coli umumnya memperlihatkan tanda-tanda klinis antara lain yaitu kurus, nafsu makan menurun dan Feed intake turun.
Pertumbuhan ayam terganggu, diare, bulu kotor atau lengket disekitar pantatnya (Tarmudji, 2003). Penelitian tentang penggunaan kombinasi $L$. acidophilus dan Bifidobacterium sp belum pernah dilakukan, sehingga perlu dilakukan penelitian untuk mengetahui efek probiotik terhadap performan ayam petelur konsumsi pakan dan hen day production (HDP) yang diinfeksi Escherichia coli.

\section{MATERI DAN METODE}

Penelitian dilaksanakan di peternakan rakyat Desa Talun Kecamatan Montong Kabupaten Tuban pada tanggal 3 November 2018 sampai 8 Desember 2018. Materi yang digunakan dalam penelitian ini adalah ayam petelur umur 25 minggu, probiotik Lactobacillus acidophilus dan Bifidobacterium sp dan Escherichia coli. Metode yang digunakan adalah penelitian eksperimental dengan menggunakan 6 perlakuan 4 ulangan, setiap ulangan berisi 5 ekor ayam petelur. Pemberian pakan sebanyak 120 g/ekor/hari dan minum dilakukan secara ad libitum selama 6 minggu (42 hari). Frekuensi pemberian pakan dilakukan 2 kali sehari, yakni pagi dan sore hari. Bakteri E. coli $10^{8} \mathrm{CFU} / \mathrm{ml}$ probiotik L.acidophilus $\quad 10^{8} \quad \mathrm{CFU} / \mathrm{ml}$ dan Bifidobacterium sp $10^{8} \mathrm{CFU} / \mathrm{ml}$. Variable yang diamati dalam penelitian ini meliputi konsumsi pakan, hen day production ( HDP) dan berat telur.

Cara pemberian probiotik yaitu melalui air minum. Kebutuhan air minum ayam per ekor per hari adalah $250 \mathrm{ml}$ sedangkan kebutuhan probiotik ayam per ekor per hari adalah $1,25 \mathrm{ml}$. Pada tiap perlakuan ayam terdiri dari 20 ekor ayam, maka kebutuhan probiotik tiap perlakuan adalah $25 \mathrm{ml} / 5$ liter air minum. Pemberian AGP melalui pakan. Penggunaan AGP ditimbang $6 \mathrm{~g} / 2400 \mathrm{~g}$ pakan/ perlakuan (20 ekor). Pemberian infeksi $E$. coli pada ayam dilakukan dengan cara disonde. Infeksi $E$. coli diberikan 2 minggu setelah perlakuan pemberian AGP dan probiotik. 
Konsumsi zat makanan dihitung dengan mengalikan konsumsi pakan harian dengan persentase zat makanan dalam pakan. Kebutuhan pakan harian untuk menghasilkan telur didasarkan pada kebutuhan energi dan protein (Amrullah, 2003). Produksi telur harian atau hen day production (HDP) adalah persentase produksi telur harian dengan jumlah ayam petelur selama pencatatan (Yurlahmen, 2008). Berat telur dihitung berdasarkan hasil penimbangan telur setiap hari selama perlakuan.

Tabel 1. Pembagian kelompok dengan faktorial

\begin{tabular}{c|cccc}
\hline & \multicolumn{2}{|c}{$\begin{array}{c}\text { Fscherichia } \\
\text { coli }\end{array}$} & \multicolumn{3}{c}{ Faktor 2 (b) } \\
\hline & & $\begin{array}{c}\text { Kontrol } \\
\text { (b0) }\end{array}$ & $\begin{array}{c}\text { AGP 0,1\% } \\
\text { (b1) }\end{array}$ & $\begin{array}{c}\text { Probiotik L. acidophilus 0,5\% dan } \\
\text { Bifidobacterium sp 0,5\% (b2) }\end{array}$ \\
\cline { 2 - 5 } Faktor 1 & Tidak (a0) & a0b0 & a0b1 & a0b2 \\
\cline { 2 - 5 } (a) & Infeksi (a1) & a1b0 & a1b1 & a1b2 \\
\hline
\end{tabular}

Keterangan :

a0b0 : Kontrol tidak diinfeksi E. coli

a1b0 : Kontrol diinfeksi E. coli

a0b1 : 0,1\% AGP

a1b1 :0,1\% AGP + Infeksi E. coli

a0b2 :0,5\% Lactobacillus acidophilus dan $0.5 \%$ Bifidobacterium $s p$

a1b2 : 0,5\% Lactobacillus acidophilus dan 0.5\% Bifidobacterium sp + Infeksi E. coli

\section{Analisis Statistik}

Pengumpulan data dilaksanakan hari terakhir penelitian. Data yang didapat dari hasil penelitian, diolah dengan menggunakan bantuan microsoft excel. Setelah data diperoleh dilanjutkan dengan tabulasi setiap minggu selama penelitian dan dianalisis dengan Rancangan Acak Lengkap Pola Faktorial 2 x 3 dengan 4 ulangan. Apabila diperoleh hasil yang berbeda nyata $(\mathrm{P}<0,05)$ maka dilanjutkan dengan Uji Jarak Berganda Duncan.

\section{HASIL DAN PEMBAHASAN}

\section{Konsumsi Pakan}

Rataan konsumsi pakan ayam yang diberi pakan dengan AGP dan probiotik disajikan pada Tabel 1.

Tabel 1. Rataan konsumsi (g) pakan ayam yang diberi pakan dengan AGP dan probiotik

\begin{tabular}{l|ccc}
\hline Faktor a & \multicolumn{3}{|c}{ Faktor b } \\
\cline { 2 - 4 } & Kontrol (b0) & $\begin{array}{c}\text { Antibiotika } \\
0,1 \%(\mathrm{~b} 1)\end{array}$ & $\begin{array}{c}\text { Probiotik L. Acidophilus 0,5\% } \\
\text { dan Bifidobcterium 0,5\% (b2) }\end{array}$ \\
\hline Non infeksi (a0) & $113.9 \mathrm{a} \pm 0.08$ & $113.8 \mathrm{a} \pm 0.08$ & $114.5 \mathrm{~b} \pm 0.53$ \\
Infeksi (a1) & $113.9 \mathrm{a} \pm 0.16$ & $113.5 \mathrm{a} \pm 0.16$ & $114.7 \mathrm{~b} \pm 0.47$ \\
\hline
\end{tabular}

Keterangan : Superskrip yang berbeda menunjukkan adanya perbedaan yang nyata $(\mathrm{p}<0,05)$

Berdasarkan hasil analisis anova menunjukkan bahwa faktor infeksi tidak menunjukkan perbedaan yang nyata $(\mathrm{P}>0,05)$ terhadap konsumsi pakan, tetapi pemberian probiotik menunjukkan perbedaan yang nyata $(\mathrm{P}<0,05)$ terhadap konsumsi pakan. Tidak terdapat interaksi antara faktor infeksi dengan probiotik $\quad(\mathrm{P}>0,05)$ terhadap konsumsi pakan.
Konsumsi pakan pada penelitian dihitung dengan pakan yang diberikan dikurangi sIsa pakan yang ada setiap 24 jam sekali. Hal ini sesuai dengan Amrullah (2003) yang menyatakan bahwa konsumsi pakan dihitung dengan cara jumlah pakan yang diberikan dikurangi dengan sIsa pakan dan pakan yang tercecer Konsumsi zat makanan dihitung dengan mengalikan 
konsumsi pakan harian dengan persentase zat makanan dalam pakan. Kebutuhan pakan harian untuk menghasilkan telur didasarkan pada kebutuhan energi dan protein. Berdasarkan tabel 1 konsumsi tertinggi terdapat pada perlakuan probiotik. Hal ini disebabkan karena pemberian probiotik menjadikan nafsu makan pada ternak tinggi. Pribadi, Kurtini dan Sumardi (2015) mengatakan bahwa probiotik juga berfungsi untuk meningkatkan penyerapan nutrisi dalam pakan.

Berdasarkan hasil penelitian perlakuan terbaik terdapat pada pemberian probiotik yang diinfeksi yaitu sebesar 114,7 g. Hal ini sesuai dengan pendapat (ISA, 2015) bahwa standart konsumsi pakan ayam petelur strain Isa brown umur 25-32 minggu sebesar $114 \mathrm{~g}$, sedangkan perlakuan terendah terdapat pada perlakuan antibiotika (AGP) yang diinfeksi yaitu sebesar 113,5. Faktor yang menyebabkan tingi rendahnya konsumsi pakan saat penelitian adalah cuaca, lama penerangan di malam hari, tingkat produksi dan kualitas pakan. Penambahan lama penerangan di malam hari yang ideal adalah 4 jam. Hal ini sesuai dengan Zahra et al. (2012) bahwa faktor yang mempengaruhi konsumsi pakan adalah umur, bobot badan, kualitas dan kuantitas pakan. Serat kasar, kerapatan jenis atau kepadatan pakan, lemak kasar (Allama et al., 2012).

Faktor lain yang berperan kurang dominan adalah galur ayam, bobot badan, berat telur, kondisi lingkungan dan aktivitas ayam (Amrullah, 2003). Faktor lain yang menyebabkan konsumsi pakan rendah pada penelitian adalah sudah tercukupinya kebutuhan nutrisi dan energi di dalam tubuh ternak. Hal ini sesuai dengan pernyataan (Natalia et al., 2016) bahwa meningkatnya ketersediaan nutrisi dalam saluran pencernaan akan menekan konsumsi dan produksi telur lebih efisien. Konsumsi pakan yang lebih rendah disebabkan karena nutrisi yang dibutuhkan ternak sudah tercukupi.

\section{Hen Day Production (HDP)}

Rataan nilai HDP ayam yang diberi pakan dengan AGP dan probiotik disajikan pada Tabel 2.

Tabel 2. Rataan nilai HDP (\%)

\begin{tabular}{l|ccc}
\hline Faktor a & \multicolumn{3}{|c}{ Faktor b } \\
\cline { 2 - 4 } & Kontrol (b0) & $\begin{array}{c}\text { Antibiotika } \\
0,1 \%(\mathrm{~b} 1)\end{array}$ & $\begin{array}{c}\text { Probiotik L. Acidophilus 0,5\% } \\
\text { dan Bifidobcterium 0,5\% (b2) }\end{array}$ \\
\hline Non infeksi (a0) & $90.7 \mathrm{c} \pm 0.16$ & $94.7 \mathrm{~d} \pm 0.18$ & $98.6 \mathrm{e} \pm 1.88$ \\
Infeksi (a1) & $73.3 \mathrm{a} \pm 0.11$ & $86.7 \mathrm{~b} \pm 0.16$ & $98.3 \mathrm{e} \pm 1.68$ \\
\hline
\end{tabular}

Keterangan : Superskrip yang berbeda menunjukkan adanya perbedaan yang nyata $(p<0,05)$

Berdasarkan hasil analisis anova menunjukkan bahwa faktor infeksi dan pemberian probiotik menunjukkan perbedaan yang nyata $(\mathrm{P}<0,05)$ terhadap HDP. Terdapat interaksi antara infeksi dengan probiotik $(\mathrm{P}<0,05)$ terhadap HDP. Penghitungan HDP pada saat penelitian dihitung per perlakuan, produksi telur dibagi dengan populasi ayam dikalikan $100 \%$. Hal ini sesuai dengan Yurlahmen (2008) yang menyatakan bahwa Produksi telur harian atau hen day production (HDP) adalah suatu produksi telur dalam suatu kelompok ayam petelur yang didasarkan atas persentase produksi telur dengan jumlah ayam petelur selama pencatatan. Faktor yang mempengaruhi produksi telur selama penelitian yaitu kualitas pakan yang diberikan dan tigkat stress pada ayam. Hal ini sesuai dengan pendapat Yurlahmen (2008) bahwa Jumlah produksi telur dipengaruhi oleh kandungan protein dan fosfor dalam pakan. Kandungan protein dalam pakan yang lebih tinggi akan menghasilkan produksi telur yang lebih tinggi pula, karena kandungan asam amino yang terdapat pada pakan tersebut lebih 
lengkap. Produksi telur tergantung dari zatzat makanan yang dikkonsumsi oleh ayam, apabila terjadi defisiensi maka pembentukan telur akan terhambat.

Berdasarkan uji lanjut DMRT (Duncan Multiple Range Test) dapat disimpulkan bahwa HDP tertinggi yaitu pemberian probiotik non infeksi yaitu 98,6\% serta pada pemberian probiotik pada ayam petelur yang diinfeksi E.coli, yaitu sebesar $98,3 \%$. Hal ini sesuai dengan pendapat ISA (2015) bahwa standart HDP ayam petelur strain Isa brown umur 26-29 minggu adalah $96 \%$. HDP terendah terdapat pada perlakuan kontrol infeksi yaitu $73,3 \%$. Hal ini disebabkan karena ayam terinfeksi E. coli mengalami penurunan nafsu makan, sehingga produksi telur menurun. Hal ini sesuai dengan Tarmudji (2003) bahwa Ayam yang terserang kolibasilosis, umumnya memperlihatkan tanda-tanda klinis: kurus, bulu kusam, nafsu makan menurun dan murung. Pertumbuhan ayam terganggu, diare, bulu kotor atau lengket disekitar pantatnya.

Pada saat penelitian posisi umur ayam sedang mencapai puncak produksi yaitu umur 25-29 minggu, sehingga produksi ayam terus mengalami kenaikan. Hal ini sesuai dengan Amrullah (2003) yang menyatakan bahwa ayam akan mampu bertelur biasanya hingga mencapai 15 bulan produksi. Tahapan produksi mulai dari umur 22 minggu kemudian meningkat tajam hingga mencapai puncak pada umur 28-30 minggu dan mulai menurun bertahap hingga mencapai produksi hatian $65 \%$ pada ummur 82 minggu. Pemberian probiotik pada saat penelitian memberikan dampak yang positif terhadap HDP karena pemberian probiotik pada ayam yag masih muda (menuju puncak) bIsa memaksimalkan kinerja reproduksi. Hal ini sesuai dengan pendapat Kompiang (2009) bahwa Probiotik sebaiknya diberikan pada awal pemeliharaan. Probiotik lebih efektif diberikan pada saat ternak masih muda. Pada ayam yang masih muda, probiotik sangat berpengaruh terhadap penyerapan nutrisi yang mempengaruhi jumlah ovum yang dihasilkan sehingga kinerja organ reproduksi maksimal dan produksi juga optimal.

Pemberian probiotik pada perlakuan meningkatkan hasil produksi yang lebih tinggi dibandingkan pemberian AGP dan kontrol karena pemebrian probiotik mampu memaksimalkan sistem kerja di dalam pencernaan. Sudaryani dan Santosa (2004) menyatakan bahwa Penambahan feed supplement dalam ransum ayam petelur sangat penting karena feed supplement berguna untuk mempercepat pertumbuhan ayam, mempertahankan dan meningkatkan produksi serta menjaga sistem kesehatan ayam. Lee dan Salminen (2009) menyatakan bahwa Lactobacillus acidophilus dapat memproduksi bakteriosin yang ditandai tidak hanya sebagai antibakteri jangkauan luas, tetapi juga mempunyai aksi penghambatan terhadap ragi tertentu.

\section{Berat Telur}

Rataan berat telur yang mendapat perlakuan Probiotik L. Acidophilus dan Bifidobcterium disajikan pada Tabel 3.

Hasil analisis anova menunjukkan bahwa faktor infeksi tidak menunjukkan perbedaan yang nyata $(\mathrm{P}>0,05)$ terhadap berat telur, tetapi pemberian probiotik menunjukkan perbedaan yang nyata $(\mathrm{P}<0,05)$ terhadap berat telur. Terdapat interaksi antara infeksi dengan probiotik $(\mathrm{P}<0,05)$ terhadap berat telur. Berat telur pada saat penelitian ditimbang satu

Tabel 3. Rataan berat (g) telur ayam yang diberi pakan dengan AGP dan probiotik

\begin{tabular}{l|ccc}
\hline Faktor a & \multicolumn{3}{|c}{ Faktor b } \\
\cline { 2 - 4 } & Kontrol (b0) & AGP 0,1\% (b1) & $\begin{array}{c}\text { Probiotik L. Acidophilus 0,5\% } \\
\text { dan Bifidobcterium 0,5\% (b2) }\end{array}$ \\
\hline $\begin{array}{l}\text { Non infeksi (a0) } \\
\text { Infeksi (a1) }\end{array}$ & $59 \mathrm{~b} \pm 1.15$ & $58.8 \mathrm{ab} \pm 0.64$ & $60.5 \mathrm{~d} \pm 0.25$ \\
\hline
\end{tabular}

Keterangan : Superskrip yang berbeda menunjukkan adanya perbedaan yang nyata $(\mathrm{p}<0,05)$ 
persatu telur dengan satuan gram pemberian probiotik pada saat penelitian memberikan efek yang positif terhadap berat telur. Faktor lain yang mempengaruhi berat telur pada saat penelitian adalah kualitas pakan dan suhu di kandang yang tidak stabil. Hal ini sesuai dengan pendapat Mampioper et al. (2008) yang menyatakan bahwa kualitas pakan yang baik dalam hal ini kandungan protein, asam amino dan asam linoleat akan mempengaruhi berat telur, karena pakan dengan kualitas yang baik dapat menghasilkan telur yang berukuran besar. Defisiensi asam amino dapat mengakibatkan penurunan produksi dan ukuran telur.

Uji lanjut DMRT (Duncan Multiple Range Test) dapat disimpulkan bahwa berat telur tertinggi yaitu pemberian probiotik non infeksi sebesar 60,5 g yang tidak berbeda dengan pemberian probiotik pada ayam petelur yang diinfeksi E.coli yaitu sebesar 60,4 g dan berat telur terendah terdapat pada perlakuan kontrol yang diinfeksi yaitu 58,3 g. Hal ini tidak sesuai dengan pendapat ISA (2015) bahwa standart berat telur ayam petelur strain Isa brown umur 28-30 minggu adalah $62 \mathrm{~g}$. Hal ini ditambahkan pernyataan oleh Yurlahmen (2008) bahwa faktor yang mempengaruhi besarnya telur adalah tingkat dewasa kelamin, protein dan asam amino yang cukup, genetik, umur ayam, obatobatan dan zat-zat makanan dalam pakan. Ukuran telur terdiri dari ukuran kecil yaitu dengan berat telur rata-rata 47,2 g, ukuran medium dengan berat telur rata-rata 47,2$54,2 \mathrm{~g}$, ukuran besar dengan berat telur ratarata 54,4-61,4 g dan ukuran jumbo dengan berat telur lebih dari 61,5 g. Hasil penelitian ini menunjukkan bahwa berat telur pada ayam yang diberi probiotik $0,5 \%$ Lactobacillus acidophilus dan $0,5 \%$ Bifidobacterium $s p$ baik yang tidak diinfeksi maupun diinfeksi E.coli, memberikan hasil produksi telur yang termasuk dalam range ukuran besar.

Pemberian probiotik telur mampu meningkatkan berat telur lebih tinggi dibandingkan perlakuan pemberian AGP dan kontrol. Pada perlakuan probiotik yang diinfeksi menghasilkan bobot telur yang lebih tinggi dibandingkan perlakuan pemberian AGP yang diinfeksi dan kontrol infeksi. Hal ini disebabkan probiotik Lactobacillus acidophilus dan Bifidobacterium $s p$ mampu menghambat pertumbuhan mikroba. Lopez (2000) menyatakan bahwa alur kerja probiotik adalah pertama menghasilkan asam, sehingga $\mathrm{pH}$ menjadi rendah, keadaan ini tidak menguntungkan bagi mikroorganisme pathogen. Kedua beberapa mikroba probiotik dapat menghasilkan bahan antimikroba (bakteriosin) yang dapat menghambat pertumbuhan mikroba lain yang tidak menguntuntungkan. Ketiga mikroba probiotik berkembang biak di dalam saluran pencernaan dan berkompetisi dengan mikroba pathogen. Keempat berkompetisi dengan mikroba pathogen untuk berikatan dengan reseptor yang sama.

\section{KESIMPULAN}

Pemberian probiotik berpengaruh terhadap konsumsi pakan, Hen Day Production dan berat telur. Faktor infeksi berpengaruh terhadap Hen Day Production dan berat telur tetapi tidak berpengaruh terhadap konsumsi pakan. Terdapat interaksi antara faktor probiotik dan infeksi terhadap Hen Day Production dan berat telur, tetapi tidak terdapat interaksi antara faktor probiotik dan infeksi terhadap konsumsi pakan. Konsumsi pakan tertinggi terdapat pada pemberian probiotik diinfeksi yaitu 114,7 g. Hen Day Production tertinggi pada pemberian probiotik noninfeksi yaitu 98,6\% dan berat telur tertinggi terdapat pada pemberian probiotik noninfeksi yaitu $60,5 \mathrm{~g}$ dan infeksi 60,4 g. Peternak diharapkan dapat memberikan probiotik L. acidophilus dan Bifidobacterium $s p$ untuk mendapatkan produksi yang maksimal.

\section{DAFTAR PUSTAKA}

Allama, H., O. Sofjan, E. Widodo dan H. S. Prayogi. 2012. Pengaruh Penggunaan Tepung Ulat Kandang (Alphitobius 
diaperius) Dalam Pakan Terhadap Penampilan Produksi Ayam Pedaging. Jurnal Ilmu-Ilmu Peternakan. 22(3): 1-8

Amrullah, I. K. 2003. Nutrisi Ayam Petelur. Satu Gunung Budi. Bogor

Haryati, T. 2011. Probiotik dan prebiotik sebagai pakan imbuhan nonruminansia. Wartazoa. 21 (3): 125-132.

ISA. 2015. Isa Brown Management Guide. A Hendrix genetics company. http://www.supremefeeds.com/wpcontent/uploads/2015/08/ISA-BrownManagement-Guide.pdf. Diakses 20 Agustus 2018

Kompiang, I. P., dan Supriyanti. 2000. Pengaruh Cara Pemberian Pecan dan Ampas Sagu Terfermentasi terhadap Kinerja Ayam Pedaging. Jurnal Ilmu Ternak dan Veteriner. 6(1): 14-20.

Lee, Y.K. and S. Salminen. 2009. Handbook of Probiotic s and Prebiotics. 2nd ed. Inc Publication. USA. 271-284.

Lopez, J. 2000. Probiotic in Animal Nutrition. Jurnal Animal Science. 13: 12-26.

Mampioper, A., S. D Rumetor dan F. Pattiselano. 2008. Kualitas Telur Ayam Petelur Yang Mendapat Ransum Perlakuan Subtitusi Jagung Dengan Tepung Singkong. Jurnal Ternak Tropika. 9(2): 42-51.

Mulyani, S., A. M. Legowo dan A. A. Mahanani. 2008. Viabilitas Bakteri Asam Laktat, Keasaman Dan Waktu Pelelehan Es Krim Probiotik Menggunakan Starter Lactobacillus casei dan Bifidobacterium bifidum. J.Indon.Trop.Anim. Agric. 33(2) : 120-125

Pribadi, A. T. Kurtini dan Sumardi. 2015. Pengaruh pemberian probiotik dari mikroba lokal terhadap kualitas indeks albumen, indeks yolk dan warna yolk pada umur telur 10 hari. Jurnal Ilmiah Peternakan Terpadu. 3 (3): $180-184$.

Ratcliff, J. 2001. European Poultry Production Without Antibiotic Growth Promotores-One Year On. Proc. Aust. Sci. Sym.

Sudaryani, T. dan H. Santosa. 2004. Pembibitan Ayam Ras. Jakarta : Penebar Swadaya.

Sumarsih, S., B. Sulistiyanto, C. I. Sutrisno dan E. S. Rahayu. 2012. Peran probiotik bakteri asam laktat terhadap produktivitas unggas. Jurnal Litbang Provinsi Jawa Tengah. 10 (1): 511-518.

Tarmudji. 2003. Kolibasilosis Pada Ayam : Etilogi Patologi Dan Pengendaliannya. Balai Penelitian Veteriner. Warta Zoa. 13(2): 65-73.

Umam, M, F., Utami, R., dan Widowati, E. 2012. Kajian Karakteristik Minuman Sinbiotik Pisang Kepok (Musa paradisiaca typical) dengan Menggunakan Bakteri Starter Lactobacillus acidophilus IFO 13951 dan Bifidobacterium longum 15707. Jurnal Teknosains Pangan. 1(1): 2-11

Yurlahmen, R. 2008. Performa Ayam Petelur Umur 21-27 Minggu yang Diberi Air Rebusan Daun Sirih (Piper bettle Linn) pada Air Minum. Progam Studi Ilmu Nutrisi dan Makanan Ternak Fakultas Peternakan IPB. Bogor.

Zahra, A. A., D. sunarti dan E. suprijatna. 2012. Pengaruh Pemberian Pakan Bebas Pilih (Free Choice Feeding) Terhadap Performans Produksi Telur Burung Puyuh (Coturnix Coturnix Japonica). Animal Agricultural Journal. 1: 1-11. 